\title{
AN ANALYSIS ON ONOMATOPOEIC WORDSAND THEIR TRANSLATION PROCEDURES IN HARRY POTTER AND THE PRISONER OF AZKABAN AND ITS TRANSLATION VERSION
}

\section{Leni Tiwiyanti}

\author{
Department of English Education, Faculty of Language and Art, University of Indraprasta PGRI \\ Jalan Nangka No. 58C Tanjung Barat, Jagakarsa, Jakarta Selatan 12530 \\ lenitiwiyanti@gmail.com
}

\begin{abstract}
Novel as the most famous genre of literature always succeeds to please its readers with its own way. It offers many stylistic language features such as onomatopoeia that can alure the readers to enter its world. Onomatopoeia is one of the most appealing feature in the novel Harry Potter and The Prisoner of Azkaban. This research discusses the onomatopoeic words. For the purpose of the research, two problems are formulated. The first problem is what word classes of onomatopoeia and the second problem of the research is on the procedures applied in translating the onomatopoeia found in the novel. This research is a qualitative and library research. Based on the analysis, there are 58 onomatopoeic words found. The onomatopoeic words are of different word classes; namely verb, noun, adjective and interjection. Most of the onomatopoeic words are verbs. There are five translation procedures used by the translator in translating the onomatopoeic words of the source text into the target text. They are borrowing ( 2 data), literal translation (14 data), transposition ( 8 data), modulation (1 data) and equivalence (33 data). Equivalence appears to be the most frequently used.
\end{abstract}

Key words: onomatopoeia, translation, novel

\begin{abstract}
ABSTRAK
Novel sebagai genre sastra yang paling terkenal selalu berhasil menghibur pembacanya dengan caranya sendiri. Novel menawarkan bermacam ciri gaya bahasa seperti onomatope yang membawa pembacanya masuk kedalam dunianya. Onomatope merupakan ciri yang paling menarik dalam novel Harry Potter and The Prisoner of Azkaban. Penelitian ini membahas tentang onomatope. Demi tujuan penelitian ini, dua masalah telah dirumuskan. Pertama adalah apa saja kelas kata dari onomatope dan masalah kedua penelitian ini adalah mengenai prosedur penerjemahan apa saja yang digunakan guna menerjemahkan onomatope yang ditemukan dalam novel tersebut. Penelitian ini menggunakan penelitian kualitatif dan kepustakaan. Berdasarkan analisis penelitian, terdapat 58 kata onomatope. Kata onomatope tersebut terdiri dari kelas kata yag berbeda; diantaranya kata kerja, kata benda, kata sifat dan interjeksi. Sebagian besar kata onomatope adalah berupa kata kerja. Terdapat lima prosedur penerjemahan yang digunakan penerjemah dalam menerjemahkan kata onomatope dalam teks sumber ke teks sasaran. Prosedur yang digunakan adalah peminjaman (2 data), penerjemahan berbasis kata (14 data), transposisi (8 data), modulasi (1 data) dan equivalence atau persamaan (33 data). Persamaan adalah prosedur yang paling sering digunakan.
\end{abstract}

Kata kunci: onomatopoeia, penerjemahan, novel 


\section{INTRODUCTION}

Literature is an art. Literary works can alure their readers to acertain level of happiness that no other art can posses. People intentionally read poetry or novel or watch a play for pleasures. Novel, as the most famous genre of literay work, which has been known since its first appearance in the eighteenth century, even never loses its readers. Many people will dive into the story instantly as they read the first page. With all its features as a work of art, novel, is always be the best choice to 'escape' from the world. It can also offer the readers some insight for certain matter.

The novel Harry Potter and the Prisoner of Azkaban by J.K. Rowling is no exception. With its own features and characteristics, the novel can take the readers, which are mostly children and teenagers, to its own world. We can categorize it as an imaginative literature. Once the readers' attention is set to the novel, the novel never stops playing the readers' imagination. In oder to keep the readers' imagination alive, there are many kinds of imageries that the author uses. The most easily spotted ones are visual and auditory imageries. In auditory imagery, the writer uses many expressions which illustrate the sound which appear inside the story. These expressions are called onomatopoeia. Onomatopoeia is defined as the fact of words containing sounds similar to the noises they describe.

Apart from its relation to translation studies, onomatopoeia itself is a very interesting study of language due to the fact that it is usually different between languages. We know that 'bang' is the expression of a gun firing in English, but we know that the equivalence is 'dor' in Indonesian. The most commonly found onomatopoeia words are of the animal sounds. There are many examples of onomatopoeia expressing animal sounds found in both languages. In English, we know that 'meow', 'baa', 'hiss', 'neigh', and 'oink' are some of English onomatopoeic words. In Indonesian we know 'mbek', 'kukuruyuk', 'meong' and 'petok' .

Translating the idea and meaning from source language into target language may not be an easy thing to do. The difference in language system and culture between English and Indonesian pose problems in translating onomatopoeia related to both languages. A good translator should consider the best equivalence that can best replace the source textinto the target text to make acceptable and readable translation result. In order to get the best equivalence, the translator should go through some translation strategies available. The best equivalence should be the one that is communicative and doesn't sound like a translation.

Onomatopoeic words are considered difficult to dealt with. Translators will not always find the equivalence of a certain onomatopoeic word of the source text in the target text. Onomatopoeia is closely related to the culture of the given language. Therefore, there is always a possibility that translators will easily find the equivalence of an English onomatopoeic word in Indonesia. The concept of culture known in English may not found in Indonesian.

In short, analyzing the translation of English onomatopoeic words into Indonesian is a very interesting thing to do. We need to see how translators deal with this unique language expression as it is not always readily found in any dictionary as some people consider it as a slang language or children language because it is commonly used in non formal communication. Chaer (2007) stated that words formulated from onomatopoeic words are listed as entry, 
but many also unregistered. Based on the discussion above, there are two main discussions in this reasearch, that is, the word classes of onomatopoeia found in the novel Harry Potter and The Prisoner of Azkaban and the translation version novel Harry Potter dan Tawanan Azkaban; and the translation procedures used in translating onomatopoeic words in the novel Harry Potter and The Prisoner of Azkaban into Harry Potter dan Tawanan Azkaban.

The Meriam-Webster Online Dictionary states that onomatopoeia is derived from the Greek onoma which means 'name' and poien which means 'to make'. Onomatopoeia is pronounced 'pnə,mætə'pi:ə' (Oxford Advanced Learner's Dictionary, 2010). Based on word category, Onomatopoeia belongs to sound symbolism, imitative sound symbolism to be exact. In Onomatopoeia, sounds are related to meaning via level of words. It is said to be the primitive communication method in which words are formed.Conventional Language Group only sees onomatopoeia as a coincidence. As stated by Chaer (2014) that most of the concept for objects, characteristics and states are expressed in different word form.In Onomatopoeia, people build words by echoing the sense by simply putting the sounds they hear into written text. The relationship between the sound and the meaning is completely conventional. Pateda (2008) defines that onomatopoeic words are words that sound similar to the sounds they represent. Onomatopoeic words in English are expressed in different expression in other languages. The words seem to hint at sounds associated with whatever is being described.

Onomatopoeia is one method how new words are created. Onomatopeia helps a language to create new words by immitating the sound of an action, a thing, an animal. In Indonesian, take the sound 'meong' which is usually used by children to refer a cat, or 'guk guk' to refer dogs. That is why onomatopoeic words occur in informal conversation (especially in conversation with/between children) more frequently than formal written language both in English and Indonesian. At first, comic writers and children story book writers are known to introduce new onomatopoeic words through their works. They help languages to develop vocabularies. More and more new words are added into the language word bank.

For writers, onomatopoeia is a commonly used sound device. Crystal (2003) stated that in traditional grammar, onomatopoeic words would be classified as a separate part of speech interjections. Onomatopoeia can also be generated as a figure of speech from sets of ordinary word wich are strategically put together (The Cambridge Guide to English Usage, 2004). We usually find it is used in poems, novels, advertisement, and surely in comics. Poets and novelist of all ages have enriched their work with onomatopoeic words. Children book writers also make use of such type of words very frequently. The onomatopoeic words help them to provide "sound" support for the concept within the work. The words are deliberately used to achieve special effect so that the readers can build up their imagination while reading the works. In comics, onomatopoeia is known to be a must. The words are even highly associated with comics. Comic readers usually find the words within balloons. In all those works of art, onomatopoeia is agreed to have its special function.

As people are more familiar to the newly onomatopoeic words, the words are developed to create new words. Onomatopoeic words are not merely 
used as interjection. As Chaer (2007) implies that many verbs are formed based on the sound immitation. In Indonesian, we usually say the dog 'menggonggong', the rooster 'kukuruyuk', the hen 'berkotek', the buffalo 'melenguh', the wind 'menderu', the tiger 'mengaum' and many more.

English onomatopoeia can easily be found in almost concise English dictionary. Many English literatures have included onomatopoeia as its main discussion and have discussed it comprehensively; however, onomatopoeia in Indonesian is not a familiar concept to discuss. Only some literatures that discuss about it but onomatopoeic words are not comprehensively mentioned. In Kamus Besar Bahasa Indonesia (1993), onomatopoeic words are "Kata-kata yang dibentuk melalui proses onomatope ini ada yang didaftarkan sebagai lema (entri), tetapi banyak juga yang tidak didaftarkan". From this point, we can see how Indonesia is still not familiar with onomatopoeic words.

Translation theory is not an instant solution for any problems that appear in translation process. It is more like a general orientation for translators to make the right decion while they are practicing the translation. Understanding translation theory is very important and useful for translators. The theory guides translators to make a good and acceptable translation. Translators distinguish between global translation strategies and local translation strategies. Global translation strategy or method is the overall strategy translators apply to a text as a whole. It is the primary choice. they have to decide how close to the source text they want their target text to be. On the other hand, local translation strategy or procedure is the kinds of strategies the translators apply in translating the individual expressions contained in the source text, such as words, grammatical constructions, idioms and many other aspects.

The focus of translation at first was only on meaning, equivalence and shift; however, they have changed the emphasis on translation theory since the end of 1950s with the work by Vinay and Darbelnet. Vinay \& Darbelnet in Venuti (2000) identify two methods of translation. The first method proposed by Vinay and Darbelnet is direct or literal translation and the second one is oblique translation. Literal translation occurs when there is an exact sructural, lexical or even morphological equivalence between the two languages. According to Vinay \& Darbelnet, this method is only possible when the two languages are very close in many respects. The oblique translation is applied due to structural and metalinguistic differences between languages. There are the procedures enumerated by Vinay \& Darbelnet in Venuti (2000), namely: 1) borrowing: transferring the sl word directly to the $\mathrm{tl}$; 2) calque: a special kind of borrowing. the sl expression or structure is literally transferred; 3) literal translation: wordfor-word translation, common between languages of the same family and culture. it disregards any contextual clues; 4) transposition: changing one part of speech for another without changing the sense; 5) modulation: changing the viewpoint and semantics of the sl; 6) equivalence: describing the same situation by different stylistic or structural means especially in translating proverbs and idioms; and 7) adaptation: changing the cultural reference when a situation in the source culture does not exist in the target culture.

Later, Hatim \& Munday (2004) classify procedures proposed by Vinay \& Darbelnet into two kinds, they are 1) direct translation covers borrowing, calque and literal translation; and 2) 
oblique translation covers transposition, modulation, equivalence and adaptation. Considering the above procedures, it might be stated that the first four procedures mostly deal with linguistic aspects of translation and the structural differences between two languages while the last three procedures mainly focus on transferring the cultural aspects of language.

Translating Onomatopoeia is problematic for translatorssince onomatopoeia has special characteristic. Haywood (2009:94) states that onomatopoeia is "directly" iconic or the phonic form of the word that is gained by immitating a sound. The relationship between the word and the meaning is highly related to "cultural conventions" and the phonological system of the given language. This "cultural convention" and phonetic system play big role in deciding the appropriate equivalence for the onomatopoeic word. For example, the onomatopoeic English word 'meow' which represents the sound made by cats which has 'meong' as its accepted equivalence in Indonesian. Some of the onomatopoeic words which are not registered in dictionary also need great consideration from each translator. The onomatopoeic 'wow', 'flump', 'whoosh' for examples, they are not easy to translate. The translators should find the acceptable equivalence without the guide of any dictionary.

In order to find the acceptable equivalence to a given onomatopoeic words, translators are demanded to be able to recognize the context where the onomatopoeic words occur. Different context where the words occur will produce diffreent meaning. Translator should be aware of the clues or message that the context try to convey. Once translators are agonized in finding the equivalence, they can look for the clues included in the context.
Casas (2001) in her journal "Translating Onomatpoeia from Chinese into Spanih: a corpus-based analysis finds three main tendencies: substitution of the original for another type of word other than an onomatopoeia (50.6\%), omission of source text onomatopoeias in the target text $(32.6 \%)$, and translation of source text onomatopoeia using a target language onomatopoeia (16.7\%). Accordingly, Wulandari (2002) in her journal "Onomatopoeia in Bilingual Children Story Books: Method and procedures of translation, finds that the translation tends to use communicative translation method that stresses on the target text understanding. The research also concludes that the procedures applied are shift or transposition, modulation, functional equivalent, and descripitive equivalence.

This research is different from the two researches mentioned above as it deals with onomatopoeic word both in English and Indonesiawhich focuses on the word classes of the onomatopoeic words and the translation procedure applied to translate from English to Indonesia. In addition to that, the source of the onomatopoeia is a novel, not comics or story books.

\section{METHOD}

This research is a qualitative reseach and library research. It is qualitative in which the researcher observes the onomatopoeic words found in the novel and its translation. The researcher alsouses theories available to analyze the words and the translation procedures applied by the translators. The data is all onomatopoeic words. The data is derrived from the novel Harry Potter: The Prisoner of Azkaban by J.K. Rowling and its translation version entitled Harry Potter danTawanan Azkaban which is translated by Listiana Srisanti. The novel by J.K. Rowling is a 
very famous among young readers. It has been translated into a number of language so far.

The data is analyzed by using such procedures, namely: 1) the researcher analyzes the source text thoroughly to recognize all onomatopoeic words used in the source text; 2) at the same time, the researcher looks for the equivalence of the onomatopoeic words given by the translator of the target text; 3) after the data are collected, the researcher checks the data in dictionary to check the meaning and make sure whether the data foundbelongs onomatopoeic words or not. the researcher consults to some dictionaries such as Oxford Advance Learner's Dictionary and Kamus Besar Bahasa Indonesia; 4) next, the researcher classifies the data based on the word class and the translation procedures used by the translator in the target text; and 5) finally, the researcher draws conclusion based on the data analysis.

\section{RESULTS AND DISCUSSION}

Based on all of the data collected, there are 58 onomatopoeic words used in the source text. The onomatopoeicwords are of different word class; namely verb, noun, adjective and interjection. Most of the onomatopoeic words are verbs.

There are five translation procedures used by the translator in translating the onomatopoeic words of the source text into the target text. They are borrowing, literal translation, transposition, modulation and equivalence.
In this discussion, the writer will present onomatopoeia words classes and the translation procedures found along with the examples. The presentation will be based on each type of onomatopoeia word class and the type oftranslation procedures by giving the example of the corresponding onomatopoeia.

\section{The Word Class of Onomatopoeic Words}

From the data analysis, the researcher finds that the data belongs to four world classes. The word classes are interjection, noun, verb and adjective. Verb is the highest number word class. The following table gives an overview of the onomatopoeic word classes.

Table 1

Onomatopoeic Word Classes

\begin{tabular}{|c|l|c|}
\hline No. & Word Classes & Total Data \\
\hline 1. & Verb & 28 \\
\hline 2. & Noun & 14 \\
\hline 3. & Interjection & 8 \\
\hline 4. & Adjective & 5 \\
\hline
\end{tabular}

\section{Translation Procedures Applied}

The followings are the translation procedures applied by the translator to translate the onomatopoeic words found in novel from English to Indonesia. Borrowing is applied to 2 data, literal translation is applied to 14 data, Transposition is applied to 8 data, modulation is only applied to 1 data, while equivalence is applied to 33 data.

Table 2

Borrowing

\begin{tabular}{|c|c|l|c|l|}
\hline No & Page & \multicolumn{1}{|c|}{ ST } & Page & \multicolumn{1}{|c|}{ TT } \\
\hline 1. & 97 & $\begin{array}{l}\text { Then there was a small } \\
\text { pop sound. }\end{array}$ & 163 & $\begin{array}{l}\text { Kemudian terdengar lagi } \\
\text { suara plop pelan }\end{array}$ \\
\hline 2. & 227 & WHOOSH & 379 & WHUSH \\
\hline
\end{tabular}


Borrowing is the taking of words directly from one language into another without translation. This procedure is done as a consuqence that Indonesian language does not have available onomatopoeic word that can best replace the english onomatopoeic word. Borrowing can be of two different nature, i.e. pure borrowing and naturalized borrowing.

There are only two data using this procedure. As shown by the examples above, we can see how the translator finnaly choose borrowing as a consequence that there is no ready equivalence of the source text. In order to keep the concept sound implied by the source text, the translator decides to use borrowing but there is a special treatment to the source text by making the source text more natural to the speaker of Indonesian.

Table 3

Literal Translation

\begin{tabular}{|c|c|l|c|l|}
\hline No & Page & \multicolumn{1}{|c|}{ ST } & Page & \multicolumn{1}{|c|}{ TT } \\
\hline 1. & 15 & ... snapped loudly. & 24 & $\begin{array}{l}\text { mengatup dengan } \\
\text { bunyi keras }\end{array}$ \\
\hline 2. & 18 & Barked uncle Vernon & 29 & Teriak paman Vernon \\
\hline
\end{tabular}

In literal translation, translators simply translate one word with another word without considering the context or writing style implied within the source text. Therefore, the data show that the onomatopoeic words are replaced by neutral words. There are 14 data using this procedure. As given by the examples mentioned above, we can see how the word 'snapped' which means 'to break something suddenly with a sharp noise' is tranlated into mengatup which means menutup rapat-rapat. The translator disregard the concept of the sharp noise made by the action. The context is not a main focus of in translating the source text. Also shown by the word barked. The translator uses an equivalence teriak which doesn't have the similar concept implied by the source text. The stylistic concept brought by the source text is not implied in the target text.

Table 4

Transposition

\begin{tabular}{|c|l|l|c|l|}
\hline No & Page & \multicolumn{1}{|c|}{ ST } & Page & \multicolumn{1}{c|}{ TT } \\
\hline 1. & 11 & Hoot & 17 & Mengucapkan uhu \\
\hline 2. & 15 & ... with a loud clunk. & 24 & $\begin{array}{l}\text { Dengan bunyi } \\
\text { berdebam }\end{array}$ \\
\hline
\end{tabular}

In this procedure, the translator changes the grammatikal category of the source text. The changes applied may be of category, structure and unit shifts. The procedure changes nouns into verbs or any other word categories, words into phrases, or clauses into sentences.
There are 8 data found using this procedure. As shown by the examples above. The word hoot is translated into mengucapkanuhu and clunk into bunyi berdebam. Words are translated into phrases. 
Table 5

Modulation

\begin{tabular}{|c|l|l|c|ll|}
\hline No & Page & \multicolumn{1}{|c|}{ ST } & Page & \multicolumn{2}{|c|}{ TT } \\
\hline 1. & 141 & $\begin{array}{l}\text { There was a buzz of } \\
\text { christmas }\end{array}$ & 236 & $\begin{array}{l}\text { Suasana } \\
\text { terasa }\end{array}$ & natal sudah \\
\hline
\end{tabular}

Modulation changes the form of the message. It is obtained by a change in the point of view of the source text. The idea is the same, but the phrases that are used in the source text and target text are different. The source text is not tranlated word-for-word.

There is only one data found which uses modulation procedure. As shown by the example above, the point of the message is to convey the coming athmosphere of christmas but the source text has different focus with the target text. In the source text, the writer focuses on the expression on how people are talking about christmas by using the word 'buzz' while the target text uses different point on view of the given concept by focusing on the christmas athmosphere. the source text uses expletive 'there' to present the idea but the target text uses suasana natal, or the christmast athmosphere as the subject.

Table 6

Equivalence

\begin{tabular}{|c|l|lc|c|c|}
\hline No & Page & \multicolumn{2}{|c|}{ ST } & Page & \multicolumn{1}{c|}{ TT } \\
\hline 1. & 11 & Flump & 16 & Pluk \\
\hline 2. & 18 & $\begin{array}{l}\text { Snorted } \\
\text { Vernon }\end{array}$ & uncle & 29 & Dengus paman Vernon \\
\hline
\end{tabular}

This translation procedure can maintain the stylistic impact of the source text in the target text. Therefore, it is an ideal method when translator has to deal with onomatopoeic words. It seems Indonesian has some equivalence for English onomatopoeic words. There are 33 data using this procedure. Some of the onomatopoeic words in Indonesian are already listed in dictionaries, but the rest are not. To deal with onomatopoeic words which are not found in dictionaries, the translators should be creative to use any similar sound used colloquially or even produce a new word. Hiwever, the last choice should be taken into account after some considerations.

The examples above show how translator can finnaly keep the stylistic impact of the source text in the target text as they are both of the same type, onomatopoeia. The first pair of words are not found either in English or in Indonesian. In this case, the translator chooses to be creative to use a word that can best convey the same message by keeping the same writing style. The translator can come up with a new onomatopoeic word, borrowing or checking any available onomatopoeic words in colloquial language. Onomatopoeic words may be commonly used in informal communication but rarely used in formal one.

\section{CONCLUSION}

The aim of this research are to obtain the onomatopoeic words in the novel Harry Potter and the Prisoner of Azkaban and to analyze the translation procedures used to deal with the onomatopoeic words by the Indonesian translator into Indonesian version. The 
researcher found 58 onomatopoeic words in the novel Harry Potter and the Prisoner of Azkaban. From the data, the researcher found that there are only five of seven translation procedures proposed by Vinay and Darbelnet which are used by the translator, namely borrowing, literal translation, transposition, modulation and equivalence.

Each of the procedures is applied to meet the need of equivalence. Borrowing is used when there is no ready equivalence for the source text which can best replace the source text. The data show naturalized borrowing. The English onomatopoeic words are borrowed with naturalization process to make them more natural for target readers. Literal translation procedure is choosen when the stylistic feature of the source text does not play an important role to the message conveyed and does not affect the meaning of the message. In this case, neutral words are used in the target text and the translation is done on word base. In transposition, the grammatical category of the source text is replaced with another. The data shows how onomatopoeic words which play as nouns are translated into verbs or any other word categories. It is also noticed that some onomatopoeic words are also translated into phrases. In modulation, the translator uses different point of view but with the same message. The subject of the source text may be the object of the target text. The equivalence procedure is the most commonly used as it will give both the same message and stylistic element of the onomatopoeic word.In this procedure, the translator should be creative, have enough knowledge and also be familiar with availabe onomatopoeic words in the target language.

Based on five translation procedures found, borrowing and equivalence can best convey the same message of the source text in the target text. By using borrowing procedure, translator can be creative to build more new onomatopoeic words which are natural and acceptable to the target text readers. This will also build new words to the target language, Indonesian language to be particular. The other three procedures, namely: literal translation, transposition and modulation, can still convey the meaning although in a different writing style. The readers cannot feel the sense of auditory imagery that the source text contain. However, the procedures are acceptable as they are still communicative and still convey the message well.

\section{REFERENCES}

Casas, H. (2001). Translating Onomatopoeia from Chinese into Spanish: a Corpus-based

Analysis. Barcelona: Campus de la UAB.

Chaer, A. (2007). Leksikologi \& Leksikografi Indonesia. Jakarta: Rineka Cipta. (2014). Linguistik Umum. Jakarta: Rineka Cipta.

David, C. (2003). The Cambridge Encyclopedia of The English Language. Italy: Cambridge University Press.

Doffs, E. (2008). Onomatopoeia and Iconicity: A Comparative Study of English and Swedish Animal Sound. Karlstad: Karlstad University.

Hatim, B. \& Jeremy, M. (2004). Translation: An Advanced Resource Book. Newyork: Routledge. 
Haywood. (2009). Thinking Spanish Translation. New York: Routledge.

Kamus Besar Bahasa Indonesia. (2008). Jakarta: PT. Gramedia Pustaka Utama.

Kridalaksana, H. (2008). Kamus Linguistik. Jakarta: Gramedia Pustaka Utama.

Meriam-Webster Online Dictionary. (2016). (http://www.meriamwebster.com) March 8. Oxford Advanced Learner's Dictionary. (2010). New York: Oxford University Press.

Pateda, M. (2010). Semantik Leksikal. Jakarta: Rineka Cipta.
Rowling, J. K. (2000). Harry Potter and the Prisoner of Azkaban. London: Clys Ltd. . (2001). Harry Potter dan Tawan Azkaban. Jakarta: PT. Gramedia Pustaka Utama.

The Cambridge Guide to English Usage. (2004). Cambridge: Cambridge University Press.

Venuti, L. (2000). The Translation Studies Reader. London and New York: Routledge.

Wulandari, R. (2002) Onomatopoeia in Bilingual Children Story Books: Method and Procedures of Translation. Surabaya: Universitas Airlangga. 